\title{
Exploring Secondary Students' Reading Motivation
}

\author{
Namgay Dukpa, Sonam Dhendup*
}

\author{
Ministry of Education, Thimphu, Bhutan. \\ *Corresponding author \\ Received: 03 Jun 2021; Received in revised form: 01 Jul 2021; Accepted: 08 Jul 2021 \\ (C)2021 The Author(s). Published by TheShillonga. This is an open access article under the CC BY license \\ (https://creativecommons.org/licenses/by/4.0/)
}

\begin{abstract}
Reading is a life-long process, and having the knowledge and skill of reading is an added advantage. Despite its importance, relatively little has been done to examine student reading motivation particularly with Bhutanese secondary students. This study aimed to identify the student factors related to reading motivation. A sample of 155 students using a simple random sampling method was recruited for this study in one Western district of Bhutan. The study was quantitative in design and have utilized a cross-sectional self-reported survey questionnaire for data collection and analyses. The researchers developed the instruments based on relevant literature and were validated by experts from Bhutan and Thailand before the pilot testing. The result of the pilot test yielded internal reliability > 0.7. The findings of the main study showed that students' opinions towards factors related to reading motivation were high with (Mean=3.90). Likewise, the results of the t-test revealed that gender did not differ in the reading motivation, and further, one-way ANOVA tests also did not show a presence of statistically significant differences student's age, parents work type, parent's level of education and finally, the parent's level of income.
\end{abstract}

Keywords-Bhutan, gender, reading, motivation, student factor, secondary students.

\section{INTRODUCTION}

Reading is used for various purposes (Kanonire et al. 2020; Kuşdemir \& Bulut, 2018). There is a growing consensus among academics, educators, and scholars that there is a strong positive correlation between reading and academic success in schools (Huang, 2013; Kuşdemir \& Bulut, 2018; Leppänen et al., 2005; Neugebauer \& Fujimoto, 2018; Vaknin-Nusbaum \& Nevo, 2017). Besides academic performance, good reading skill is these days essential even in the workplaces. In recent years many research initiatives were undertaken, for instance, in the United States and the United Kingdom, to help identify and then implement quality reading intervention programs to improve student learning and achievement (Baye et al., 2018).

Comparably, the Bhutanese education system also places the importance of reading as it's core domain of English language learning from pre-primary to level Twelve curricula (Royal Education Council [REC], 2021). Though importance is given to improving students' reading performance, the reading performance of students in Bhutan said to be one of the most critical problems faced by the Bhutanese Education system. Past education policy guidelines reported that $37 \%$ of the nation's fourth-graders failed to demonstrate they can read at a basic level (Ministry of Education, 2004). Congruently, the report further corroborated that literacy and numeracy achievement at the primary level was inferior as per the international standard. The PISA-D test conducted in 2017 with Bhutanese secondary students who are 15 years old 'performance presented several issues related to reading. The findings stated that reading performance was about 38 to 48 points (percentage points) below the per cent correct values of PISA reference countries' (BCSEA, 2019, p 17). Besides, this study also claimed that a small portion of students did not complete the test due to a lack of reading fluency. Moreover, Bhutanese secondary children were not able to answer complex questions correctly and the delta values ranged between 14.3 to 19.7 (BCSEA, 2019). Going by the PISA-D test reports, reading gaps continue to exist in secondary school reading performance. It has also been found, reading difficulties may also lead to other problems, such as a lack of motivation and engagement, high levels of anxiety, and misbehaviour in the classroom (Lane, 2002). 


\section{Research hypotheses}

The following research hypothesis was considered for the study;

Ho1: There is no significant difference between male and female students' attitude towards reading

Ho2: Sample means related to reading motivation of students is statistically different by their age level

Ho3: Sample means related to reading motivation of students is statistically different by their parents' work

Ho4: Sample means related to students' reading motivation is statistically different by their parents' educational background.

Ho5: Sample means related to students' reading motivation is statistically different by their parents' socioeconomic backgrounds.

\section{LITERATURE REVIEW}

Numerous researchers in the past have studied factors that affected the reading motivation of students. Conspicuously, motivation has been found to have a substantial effect on student's achievement and other academic related-tasks (Griffin et al., 2020; Hubbard et al., 2021; Kanonire, 2020). Specifically (Griffin, 2020) study suggested that the intrinsic motivation was found to affect students' learning significantly rather than the extrinsic factor. Conversely, Kanonire et al. (2020) study carried out in Russian context found some what a different result. Their study investigated the mediation effect of reading motivation in grade 1 and their performance in Grade 3 using a longitudinal data. The findings of their study showed that both intrinsic and extrinsic motivation significantly predicted reading performance in grade 3 . While the research on reading remains to be contested, findings of the other studies also indicated that the amount of reading is determined by cognitive and motivational constructs, which is consistent with an engagement perspective on reading development (Kanonire, 2020; Kelley \& Decker, 2009).

Correspondingly, in many studies, gender scholarship towards reading tended to receive enormous attention (Kanonire et al., 2020; Mata, 2011; McGeown et al., 2011). Nevertheless, results lent inconsistencies in their findings and this is not at all surprising given the cultural context and emphasis it receives at home and in schools. For instance, McGeown et al. (2011) and Wangchuk and Zangmo (2021) studied the differences between gender in their reading skill and their attitude towards reading motivation. These two studies did not find any statistically significant difference between the gender. In contrast, Kanonire et al. (2020) found that girls performed comparatively better in reading compared to boys in young learner's context. Even in the secondary level reading, the results of the gender-wise comparison showed that female learners outperformed their male counterparts in reading by at least 3 per cent (BCSEA, 2019). Findings revealed that students' motivation to read and the value of reading declined as grade level increased differed according to gender (Kelley \& Decker, 2009).

Notably, from the literature, it points that students' confidence, types of reading material available to students, students' ability to choose reading material, teachers and classroom environment and the types of activities affected students' reading motivation (Buchanan, 2009; Baker \& Scher, 2002; Chassee, 2008; Gambrell, \& Mazzoni, 2015; Kanonire et al., 2020). Kelley and Decker (2009) study examined middle school students' motivation to read using an adapted version of the Motivation to Read Profile (MRP) Survey. The MRP is comprised of items assessing students' self-concepts and their value of reading. However, selfconcept remained stable and was more significant than students' value of reading. Further, self-concept as a reader, the value a reader attaches to reading, has been proven to be a critical factor in student reading motivation (Griffin et al., 2020; Hubbard, 2021; Powell et al., 2006). Chassee (2008) studied the Classroom Factors that Negatively Impact Reading Motivation concerning classroom practices and reading experiences in schools. The participants in that study were third-grade students in a Suburban Northwest Ohio School district. The researcher found out that the students who are motivated will do anything to read. On the other hand, unmotivated students will do anything not to read. In addition to this, the researcher also found out that the following classroom elements help promote reading motivation and they are: the ability to choose reading materials, access to books or reading materials, interactions with others about books, the teacher as a reading model, and tying reading to personal interest.

Baker \& Scher (2002) studied "Beginning readers' motivation for reading concerning parental beliefs and home reading experiences." Sixty-five 6-year-olds (first graders) from different socio-cultural backgrounds and their mothers participated in a study examining children's motivation for reading concerning parental beliefs and home literacy experiences. Results revealed that the beginning readers generally had positive views about reading and that no differences in motivation were associated with income level, ethnicity, or gender. Children's motivation for reading was not associated with the frequency of storybook reading or library visits, but 
frequent use of basic skills books (ABC books) was negatively associated with motivation. The study demonstrated the importance of looking beyond quantitative indices of home literacy experiences in accounting to develop motivation for reading. While many factors affect students' reading motivation, limited research is carried out among secondary students considering student factors, parents' work type, parents' educational level, and the socioeconomic factors that affected students' reading motivation are sparse, particularly in the Bhutanese context. This study, therefore, is an attempt to fill in the literature gap and contribute to both international and local scholarship about the factors that were indicated in this study.

\section{METHODOLOGY}

\subsection{Participants and Procedure}

This study utilizes a quantitative research design. The purpose of this study was to examine secondary students' motivation towards reading in few of Bhutanese schools. The total population for the study was 260 grade 7, 8 and 9 students. However, the total sample for the study was only 155 students. The sample size was drawn based on (Krejcie \& Morgan, 1970) determining sample size chart. The sample comprised of male $(52.3 \%)$ while female representation was $47.7 \%$. The participant ages ranged between 13-16 years. The majority of the respondents' parents in the 'others' category almost representing $(54.27 \%)$. The detailed information is presented in Table 1.

Table 1: Demographic details of the respondents $(n=155)$

\begin{tabular}{|c|c|c|c|}
\hline & Items & Fre & Per cent \\
\hline \multirow{2}{*}{ Gender } & Male & 81 & 52.3 \\
\hline & Female & 74 & 47.3 \\
\hline \multirow{3}{*}{ Age } & Below 13 & 9 & 5.8 \\
\hline & $14-15$ & 77 & 49.7 \\
\hline & Above 16 & 69 & 44.5 \\
\hline \multirow{3}{*}{$\begin{array}{c}\text { Parents Job } \\
\text { Type }\end{array}$} & Private & 54 & 34.8 \\
\hline & $\begin{array}{c}\text { Civil } \\
\text { servants }\end{array}$ & 30 & 19.4 \\
\hline & Others & 84 & 54.2 \\
\hline \multirow{4}{*}{$\begin{array}{c}\text { Parents } \\
\text { Education }\end{array}$} & Primary & 81 & 52.3 \\
\hline & Secondary & 33 & 21.3 \\
\hline & College & 41 & 26.5 \\
\hline & below 15000 & 65 & 41.9 \\
\hline
\end{tabular}

\begin{tabular}{cccc} 
Parents & $16000-30000$ & 48 & 31.0 \\
Income & above 30000 & 42 & 27.1 \\
\hline & Total & 155 & 100 \\
\hline
\end{tabular}

\subsection{Instrumentation}

The research instruments in this study comprised of two parts: Part A: Personal information consisted of questions concerning student's personal information such as age, gender, parent's educational background, occupation and income. Part B consisted of factors related to students' reading motivation. The data was collected by using a self-reported questionnaire based on literature. Each of them used a five-point Likert scale (Rensis Likert, 1932) that measured the degree of agreement with the statement: 1-Strongly disagree; 2-Disagree; 3-Neutral; 4Agree and 5-Strongly agree. The validity of the instrument was examined by a panel of experts from Thailand and Bhutan. The revised version of the questionnaire was pilottested with 20 students from non-sampling schools who shared similar characteristics with the study respondents. The reliability of the pilot-test revealed Cronbach's alpha coefficient of 0.82 , more significant than the cut-off criteria of > 0.7 (George \& Mallery, 2003).

To understand and compare students' reading motivation, the items were summed up and divided by the number of items in the context. This calculation resulted in a context having a potential range of 1 to 5 . Table 2 shows that a low score represents low opinions on factors affecting reading motivation, whereas a high score represents high opinions on factors affecting reading motivation. The dependent variable which was examined in this study was the reading motivation of students in Secondary schools. The independent variables were gender, age, parents' work, parents' education, parents' income, school factor, and student factor.

Table 2: Guidelines for understanding the means of students' opinions

\begin{tabular}{lc}
\hline Scale for mean & $\begin{array}{c}\text { Level of opinions on } \\
\text { the components of } \\
\text { evaluation in the } \\
\text { questionnaire }\end{array}$ \\
\hline $1.00-1.50$ & Lowest \\
$1.51-2.50$ & Low \\
$2.51-3.50$ & Moderate \\
$3.51-4.50$ & High \\
$4.51-5.00$ & Highest
\end{tabular}


The researchers calculated Cronbach's alpha coefficient for internal consistency reliability for the scales. For the analysis of the data, the summated scales for all the items were used. Using Cronbach's formula, the reliability coefficient for the 12 items was .89 , which indicated excellent or greater internal consistency of the items in the scale.

\subsection{Data collection and Analysis}

The researchers visited the sample schools in person and collected the data. The data obtained from each student were scrutinized, grouped and tabulated to facilitate the analysis process. Moreover, before conducting the data analyses, the data were screened using descriptive statistics by checking the values for means, SDs, minimum and maximums of the variables within the corrected and final data. Descriptive statistics such as frequencies, percentages, means and standard deviation were used to analyze the data. The inferential statistics used were independent samples t-test and one-way analysis of variance (ANOVA). The hypotheses were tested using $I p$ $<0.05]$.

\section{RESULTS}

This study aimed to examine the factors related to the reading motivation of students in Secondary schools. The responses obtained were 100 per cent.

\subsection{Factors affecting reading motivation of students}

Past research in reading revealed that there was no single factor that affected students' reading motivation. There would be numerous factors that affect students' reading motivation. The research found some common factors that had an impact on the reading motivation of students considerably. Table 3 shows that the overall opinions of the respondents on factors affecting reading motivation about student factor were responded high. From the 12 items, five items were responded highest, and two factors were responded moderately by the respondents, i.e. "My parents have a variety of books for me to read" and "A family member sometimes reads out loud to me." The highest mean score of 4.46 indicated that students liked people who read many books. It was evident that students are motivated to read whenever they found people reading around them. The lowest mean score of 3.21 reminded them that their parents have no books at home to read at their own pace and time.

Table 3: Students' Opinions on reading motivation

\begin{tabular}{llccc}
\hline Item & Student Factor & Mean & S.D & Level of opinions \\
\hline 1 & I prefer to choose my own reading materials. & 4.25 & 0.83 & High \\
2 & I like to read independently. & 3.98 & 0.93 & High \\
3 & Reading is a great way to spend time. & 4.24 & 1.11 & High \\
4 & I like people who read a lot of books. & 4.46 & 0.8 & High \\
5 & I enjoy reading both in class and outside it. & 4.19 & 0.84 & High \\
6 & I am willing to work hard to read better. & 4.41 & 0.71 & High \\
7 & Whenever I don't understand when I read, I use previous knowledge. & 3.95 & 0.87 & High \\
8 & I read a lot of books. & 3.92 & 0.95 & High \\
9 & My parents share stories that they have read. & 3.59 & 1.19 & High \\
10 & My parents have a variety of books for me to read. & 3.21 & 1.31 & Moderate \\
11 & A family member sometimes reads out loud to me. & 3.10 & 1.33 & Moderate \\
12 & My family members encourage me to read. & 4.35 & 1.02 & High \\
\hline Total & & 3.97 & 0.99 & High \\
\hline
\end{tabular}

Research hypothesis 1 was tested using a t-test. An independent-samples t-test was run to determine if there were differences in reading motivation based on gender. There were no missing and outliers in the data as assessed by the box plot. However, data presented the presence of homogeneity of variance $(p=.001)$, thereby violating the assumption of homogeneity of variance; hence, $\mathrm{t}-\mathrm{value}$ for equal variance not assumed is considered (See Table 1). A statistically significant difference of $[-0.220$ (95\% CI, 0.431 to -0.009$), \mathrm{t}(149)=-2.0, \mathrm{p}=0.001, \mathrm{~d}=<0.20]$ was recorded for reading motivation. Hence, no significant difference between male and female students towards the 
reading is rejected (see Table 4). Cohen's d = $(\mathrm{M} 2$ - M1)/SDpooled SDpooled $=\sqrt{ }((\mathrm{SD} 12+\mathrm{SD} 22) / 2)$ was calculated using this formula.

Table 4: Results of independent samples $t$-test by gender

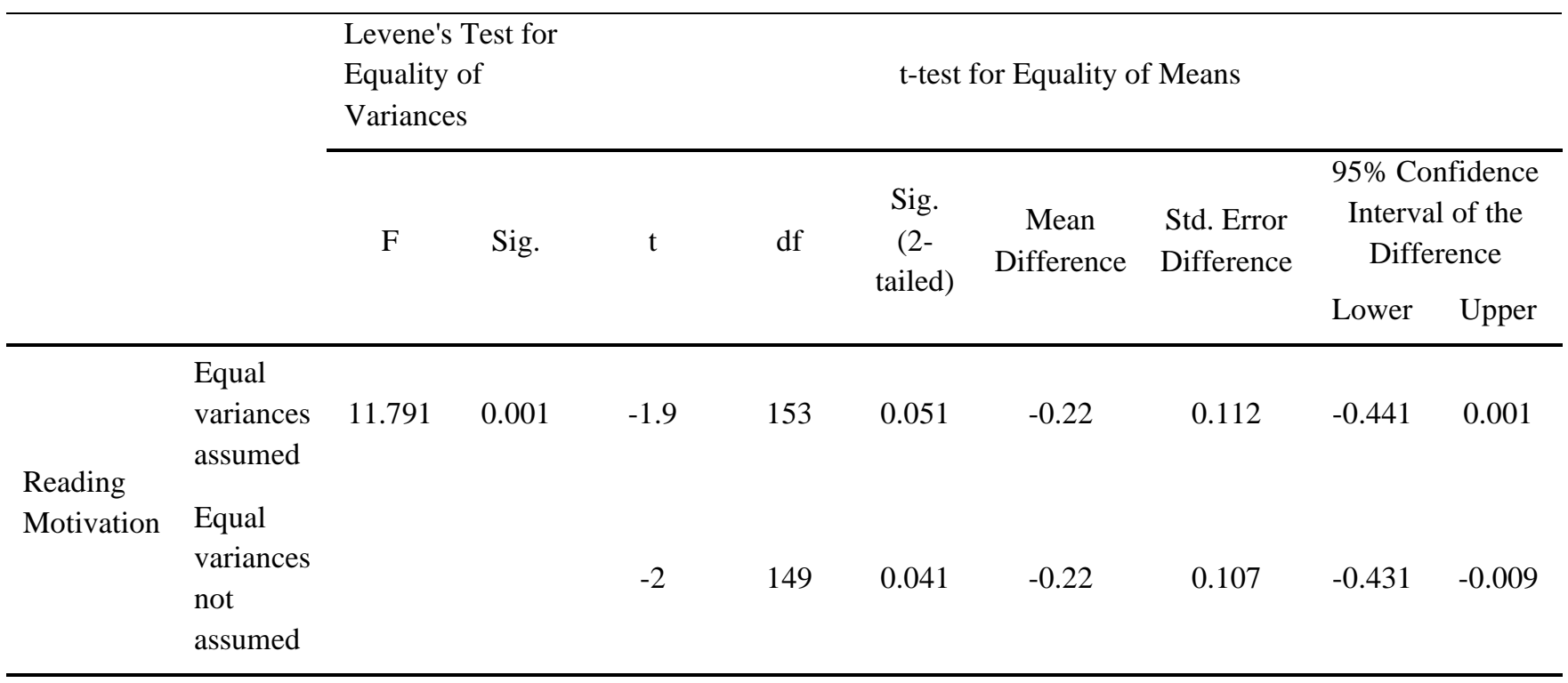

In order to determine the differences in the respondents' opinions on factors affecting reading motivation, a one-way ANOVA was used. Table 5 shows $(p=0.215)<0.05$ confirmed that there was no significant difference in the respondents' opinions regarding student factors on reading motivation. The findings presented in Table 6 further suggests that parents' educational background, parents work, and students age were not found to have statistically significant in an opinion on factors affecting students' reading motivation. The Omega squared $\left(\omega^{2}\right)$ effect size was computed using the formula: $\omega 2=$ $($ SSeffect $-($ dfeffect $)(M S e r r o r)) /$ MSerror + Sstotal. The effect size was 0.20 , thus showing a small effect size.

Table 5: One-way ANOVA based on student factor

\begin{tabular}{lccccc}
\hline Student factor & Sum of squares & df & Mean & F & Sig. \\
\hline Between groups & 7.785 & 26 & .299 & & \\
Within groups & 30.886 & 128 & .241 & 1.241 & .215 \\
Total & 38.671 & 154 & & & \\
\hline
\end{tabular}

Table 6: One-way ANOVA based on factors related to students' reading motivation.

\begin{tabular}{|c|c|c|c|c|}
\hline Factors & df & Mean Square & $\mathrm{F}$ & Sig \\
\hline Parent's Job type & 4 & 0.593 & 2.45 & 0.059 \\
\hline Parent's level of Education & 4 & 0.246 & 0.979 & 0.421 \\
\hline Parent's income level & 4 & 0.464 & 1.892 & 0.115 \\
\hline Student age & 4 & 0.502 & 2.055 & 0.09 \\
\hline
\end{tabular}


Table 7: Test of the hypothesis of the study

\begin{tabular}{lll}
\hline Item & Hypothesis & Results \\
\hline 1 & $\begin{array}{l}\text { There is no significant difference between male and female students' attitude } \\
\text { towards the reading }\end{array}$ & Reject \\
2 & $\begin{array}{l}\text { Sample means related to the reading motivation of students is statistically } \\
\text { different by their age level. }\end{array}$ & Reject \\
3 & $\begin{array}{l}\text { Sample means related to reading motivation of students is statistically different } \\
\text { by their parents' work. }\end{array}$ & Reject \\
4 & $\begin{array}{l}\text { Sample means related to reading motivation of students is statistically different } \\
\text { by their parents' educational background. }\end{array}$ & Reject \\
5 & $\begin{array}{l}\text { Sample means related to reading motivation of students is statistically different } \\
\text { by their parents' socioeconomic backgrounds. }\end{array}$ & Reject \\
\hline
\end{tabular}

\section{DISCUSSION}

This study intended to find out the factors that affect the reading motivation of secondary students in one Western district schools.

\subsection{Student factor}

The results of the study indicated that the student factor in capturing their attitude to reading. The results suggest that about $58.1 \%$ of the respondents strongly agreed, and $25.8 \%$ agreed with that statement. Further, $51 \%$ of the respondents were determined to work hard to read better. Besides, their parents, too, really gave a strong emphasis on their children's reading literacy.

Positive attitudes towards reading and parental emphasis on their children's reading played an essential role in developing students' lifelong love for reading literacy. Students who have developed positive attitudes and self-concepts regarding reading are more likely to choose reading for recreation. When children read on their own time, they are not only demonstrating a positive attitude; they are also gaining valuable experiences in reading different types of texts that further their development as proficient readers (Leppanen et al., 2005).

Research has also repetitively shown that students with greater self-efficacy or higher self-esteem about themselves as readers typically are better readers. Students need to have a strong self-concept about their reading ability to continue building on current levels of learning to move to higher plateaus (Enyeart et al., 2005). Therefore, students' performances in reading level rely on how confident and efficacious they are. The more confident and efficacious they are, the better their reading performance will be than those who lack self-confidence and are not efficacious.

\subsection{Students' positive attitudes toward reading}

A positive attitude toward reading is one of the essential attributes of a lifelong reader. Children who read well typically display a more positive attitude than children who have not had a great deal of success with reading (Martin et al., 2007). According to self-concept theory, students who have developed positive attitudes and selfconcepts regarding reading are more likely to choose reading for recreation. When children read on their own time, they are not only demonstrating a positive attitude, and they are also gaining valuable experiences in reading different types of texts that further their development as proficient readers (Leppanen et al., 2005). Therefore, students' levels of reading motivation rely on how they view themselves as readers.

\subsection{Student attitudes toward learning to read}

Research has shown that students with greater selfefficacy or higher self-esteem about themselves as readers typically are better readers. Students need to have a strong self-concept about their reading ability to continue building on current levels of learning to move to higher plateaus (Enyeart et al., 2005). Learning to read well involves spending considerable time reading, and students' value for reading and their preferences for reading materials can influence the time they spend reading both in and outside of school. Therefore, it could be said that the attitude of the students affected reading motivation.

\subsection{Gender}

The result indicated that the overall students' opinion on factors related to reading motivation was high for both male and female. The study also demonstrated that there was no statistical difference between gender and motivation to read. The findings of the study supported the research by McGeown et al. (2011) on the topic titled "Gender differences in reading motivation: does sex or gender identity provide a better account?" This study 
examined gender differences in reading skill and reading motivation, investigating whether these differences could be better accounted for by gender identity. The study revealed that there were no gender differences in reading skill or extrinsic reading motivation. However, the study contradicted the findings of Mata (2011), and BCSEA (2019) found that females were likely to have higher reading motivation than their counterparts were.

The non-significant difference between the male and female students' reading motivation could be due to the free interaction between male and female students. It might also be because both male and female students have an equal perception of what success was all about. In other words, the female students did not feel inferior to their male counterparts, and thus they were able to compete favourably with them. It appeared that the male students did not also feel superior to their female counterparts. Thus, it implied that both had an equal opportunity; hence, no gender differences occurred in their level of reading motivation.

\subsection{Age}

The study's findings revealed that the overall students' opinion on factors related to reading motivation of all age groups; 13 years or below, 14-15 years and 16 years or above was high. When compared each age group to one another, it was observed that 14-15 years old students had higher reading motivation than any other age groups. The students who were at the age of 13 years had higher reading motivation than 14-15 years, old students. Thus, it could be concluded that the older the students get, the lower the reading motivation is. The study's finding too supported the study done by Kelley and Decker (2009) on "The State of Motivation to Read among Middle School Students." The findings from their study revealed that those students' reading motivation and value of reading declined as grade level increased according to gender.

Reading achievement grows stronger with age, at least into the junior high years (Kush et al. 2005). While research pointed to the importance of reading motivation and frequency for reading achievement, there was, however, also a large body of evidence indicating that older children and adolescents have fewer positive attitudes and motivation for both academic and recreational reading than younger children and, accordingly, read less frequently (e.g., Jacobs et al., 2002; Kush \& Watkins 1996; McKenna et al., 1995). The decline in reading attitudes was further noted as students moved up the year levels, which aligns with McKenna et al.'s (1995) findings. Attitudes towards recreational and academic reading were more negatively correlated with increasing age (McKenna et al., 1995).

\subsection{Parent's work}

The research findings showed that the overall students' opinions on factors related to the reading motivation of secondary students of one Western District in Bhutan compared the level of parents' work. There was no significant difference statistically concerning parents' work. The non-significant difference between the parents' occupation could be due to the free interaction between students from different parents' occupational background. It might also be because all students had an equal perception of what reading was all about. In other words, they did not feel inferior to each other, and thus they were able to compete favourably with them. The findings, therefore, implied that the students thrive and collaborate when a co-education system exists, hence, no differences occurred in their level of reading motivation.

\subsection{Parents educational level}

The findings of our study revealed that overall student' opinions on factors related to reading motivation about the parents' educational level of students were high. However, the study's finding was not significant about parents' education level in students' reading motivation. Hence, the study's findings did not support the research of Hammer et al. (2014).

\subsection{Parents socioeconomic background}

The findings of the research about parents' socioeconomic background too fell at the range of high opinion. Conversely, no statistically significant difference was found between parents' socioeconomic background to that of reading. The findings from our study supported the results of previous research by Baker and Scher (2010). Their study also found that the beginning young readers generally had positive views about reading and that no differences in motivation were associated with income level, ethnicity, or gender. Thus, it could be concluded that parents' socioeconomic background has no impact on students' reading motivation.

\section{CONCLUSIONS}

This study attempted to examine factors related to students' reading motivation of Secondary students in one Western district in Bhutan. The purpose of this study was to examine the possible significant differences of the students on factors affecting their responses on factors related to reading motivation in relation to the individual factors such as gender, age, type of parent's work, level of parents' educational background, and socioeconomic background of parents. The findings from the study resulted in recommending concerned authorities or educators to devise some strategies to boost students' reading motivation. The findings from this study revealed 
that the overall students' opinions on factors related to reading motivation were high at a mean of 3.90 .

The research findings showed that the overall students' opinions on factors related to reading motivation of Bhutanese secondary students were found to be high when compared to parents' work type, students' age group, parents' educational level, and finally similar high results were also observed with parents' socioeconomic background items.

\subsection{Recommendations from the findings}

A structured approach to literacy sessions is established and implemented with students across all primary year levels. Although students' reading motivation was high with regard to student factor, teachers still need to give more opportunities to update their reading literacy.

This study was focused on factors related to student's reading motivation among Secondary school students in Bhutan. Through the study's findings, the researchers hope that awareness is necessary for children to read at home. The findings will also inform parents and their role in their child's education, particularly reading at home. Future studies should take into consideration a higher number of sampling that may be representative of Bhutanese secondary students rather than just a few schools within a district. Also, future studies should study amalgamate other factors other than only student factors to raise generalizability and usability. A deeper understanding of the reading motivation of student factor could be obtained through a qualitative or mixed-method study design. Further, a separate study on parent's perceptions of reading is strongly recommended. Lastly, a study on factors related to students' reading motivation in various subjects would be of great benefit for subject teachers in determining students' performance.

\section{REFERENCES}

[1] Baker, L., \& Scher, D. (2010). Beginning readers'motivation for reading in relation to parental beliefs and home reading experiences. Reading psychology, 23(4), 239-269. Https://doi.org/10.1080/713775283

[2] Baye, A., Inns, A., Lake, C., \& Slavin, R. E. (2018). A Synthesis of Quantitative Research on Reading Programs for Secondary Students. Reading Research Quarterly. https://doi.org/10.1002/rrq.229

[3] Bhutan Council for School Examinations and Assessment (2019). Education in Bhutan: Findings from Bhutan's experience in PISA for development. National Project Centre, Bhutan Council for School Examinations and Assessment

[4] Chassee, E. N. (2008). Children speak out on classroom factors that negatively impact reading motivation (Doctoral dissertation, Bowling Green State University). https://etd.ohiolink.edu/

[5] Gambrell, L. B. (2015). Getting students hooked on the reading habit. The Reading Teacher, 69, 259-263. https://doi.org/10.1002/trtr.1423

[6] George, D., \& Mallery, P. (2003). Reliability analysis. SPSS for Windows, step by step: a simple guide and reference, 14th edn. Boston: Allyn \& Bacon, 222-232.

[7] Griffin, R.A., Farran, L.K., \& Mindrila, D. (2020): Reading Motivation in Bi/Multilingual Latinx Adolescents:An Exploratory Structural Equation Model, Reading Psychology. https://doi.org/10.1080/02702711.2020.1801540

[8] Hammer, C. S., Hoff, E., Uchikoshi, Y., Gillanders, C., Castro, D. C., \& Sandilos, L. E. (2014). The language and literacy development of young dual language learners: A critical review. Early childhood research quarterly, 29(4), 715-733. https://doi.org/10.1016/j.ecresq.2014.05.008

[9] Hubbard, K. (2021). Disciplinary literacies in STEM: what do undergraduates read, how do they read it, and can we teach scientific reading more effectively?, Higher Education $\quad$ Pedagogies, 6:1, 41-65, https://doi.org/10.1080/23752696.2021.1882326

[10] Huang, S. (2013). Factors Affecting Middle School Students' Reading Motivation in Taiwan. Reading Psychology, 34(2), 148181. http://dx.doi.org/10.1080/02702711.2011.618799

[11] Kanonire,T., Lubenko, L., \& Kuzmina, Y. (2020): The Effects of Intrinsic and Extrinsic Reading Motivation on Reading Performance in Elementary School, Journal of Research in Childhood Education. https://doi.org/10.1080/02568543.2020.1822961

[12] Kelley, M. J., \& Decker, E. O. (2009). The current state of motivation to read among middle school students. Reading Psychology, 30(5), 466-485. https://doi.org/10.1080/02702710902733535

[13] Kush, J. C., Watkins, M. W., \& Brookhart, S. M. (2005). The temporal-interactive influence of reading achievement and reading attitude. Educational Research and Evaluation, 11(1), $29-44$. https://doi.org/10.1080/13803610500110141

[14] Kuşdemir, Y., \& Bulut, P. (2018). The Relationship between Elementary School Students' Reading Comprehension and Reading Motivation. Journal of Education and Training Studies Vol. 6, No. 12; https://doi.org/10.11114/jets.v6i12.3595

[15] Leppänen, U., Aunola, K., \& Nurmi, J. E. (2005). Beginning readers' reading performance and reading habits. Journal of Research in Reading, 28(4), 383-399. https://doi.org/10.1111/j.1467-9817.2005.00281.x

[16] Likert, R. (1932). A technique for the measurement of attitudes. Archives of psychology.

[17] Martin, M. O., Mullis, I. V., Kennedy, A. M., Campbell, J., Foy, P., Gonzalez, E. J., ... \& Schwippert, K. (2007). PIRLS 2006 Technical Report. TIMSS \& PIRLS International Study Center. 
[18] Mata, L. (2011). Motivation for reading and writing in kindergarten children. Reading Psychology,32(3), 272299. https://doi.org/10.1080/02702711.2010.545268

[19] McKenna, M. C., Kear, D. J., \& Ellsworth, R. A. (1995). Children's attitudes toward reading: A national survey. Reading research quarterly, 934-956. https://doi.org/10.2307/748205

[20] McGeown, S., Goodwin, H., Henderson, N., \& Wright, P. (2011). Gender differences in reading motivation: Does sex or gender identity provide a better account? Journal of Research in Reading, 35(3), 328-336. https://doi.org/10.1111/j.1467-9817.2010.01481.x

[21] McLaughlin, M., McGrath, D. J., Burian-Fitzgerald, M. A., Lanahan, L., Scotchmer, M., Enyeart, C., \& Salganik, L. (2005). Student content engagement as a construct for the measurement of effective classroom instruction and teacher knowledge. Washington, DC: American Institutes for Research.

[22] Ministry of Education (2004). 23 $3^{\text {rd }}$ Education policy Guidelines and Instructions. Policy and Planning Division.

[23] Neugebauer, S.R. \& Fujimoto, K. A. (2018). Distinct and Overlapping Dimensions of Reading Motivation in Commonly Used Measures in Schools. Assessment for Effective Intervention 1-16. https://doi.org/10.1177/1534508418819793

[24] Royal Education Council (2021). English Curriculum Framework. Classes PP-XII. REC.

[25] Vaknin-Nusbaum, V. \& Nevo, E. (2017). A joint interactive storybook intervention program for

[26] preschool and kindergarten children. Reading Psychology, 38, 231-261. https://doi.org/ $10.1080 / 02702711.2016 .1258376$

[27] Wangchuk, C., \& Zangmo, C. (2021). Reading Attitude of Students of a Middle School and Effects of a Two-year Inclass Reading Intervention on Them. Bhutan Journal of Research and Development. 10 (1); 1-24. Institute for GNH Studies. 